\title{
The relationship between anxiety and serum Urotensin-II and S100B levels in patients with essential hypertension
}

\author{
Esansiyel hipertansiyonlu hastalarda anksiyete ile serum ürotensin-ll ve \\ S100B seviyeleri arasındaki ilişki \\ Aslı Kazğan¹, Sevda Korkmaz², Sevler Yildiz³, Hasan Korkmaz, Selda Telo5, Murad Atmaca6 \\ $1_{M}$ M.D., Siverek State Hospital, Department of Psychiatry, Şanlıurfa, Turkey https://orcid.org/0000-0002-0312-0476 \\ ${ }^{2}$ Assoc. Prof., 6 Prof., Fırat University, Medical Faculty, Department of Psychiatry, Elazığ, Turkey https://orcid.org/0000-0002-0005-8232- \\ https://orcid.org/0000-0003-2772-4124 \\ ${ }_{3}^{3}$ Assis. Prof., Binali Yıldırım University, Medical Faculty, Department of Psychiatry, Erzincan, Turkey https://orcid.org/0000-0002-9951-9093 \\ ${ }_{4}^{4}$ Prof., Fırat University, Medical Faculty, Department of Cardiology, Elazığ, Turkey https://orcid.org/0000-0001-8455-6724 \\ ${ }^{5}$ Assoc. Prof.,Fırat University, Medical Faculty, Department of Biochemistry, Elazığ, Turkey https://orcid.org/0000-0003-3655-0269
}

\section{SUMMARY}

Objective: In hypertensive people, some biochemical parameters that are associated with oxidative stress and endothelial functions may play a role in the manifestation of anxiety symptoms, and even in the intensification of clinical symptoms of the disease. The purpose of our correlative study is to examine the association between anxiety severity and levels of oxidative stress parameters of Urotensin-II and S100B protein in patients with essential hypertension. Method: A total of 153 patients, who have applied Sociodemographic and Clinical Data Form, Beck Anxiety Inventory (BAI), Beck Depression Inventory and venous blood samples were taken after blood pressure measurement. S100B and Urotensin-II levels were measured with Enzyme-Linked Immunosorbent Assay method. Results: A positive correlation was determined between depression and anxiety scores, and systolic blood pressure $(p=0.049, r=0.160 ; p<0.01, r=0.292)$. There was a positive relation between BAl scores and Urotensin-II levels $(p=0.043, r=0.164)$. A positive correlation was determined between Urotensin-II levels and S100B levels $(p<0.01, r=0.711)$. A statistically significant difference was observed in serum Urotensin-II levels between depression group and no depression group $(p=0.017)$. Discussion: It was determined in our study that Urotensin-II level increased with increasing anxiety level in essential hypertension patients. It was also determined that Urotensin-II level was higher in hypertensive patients with depression compared to patients who don't have depression. Our study will shed light on new studies that will investigate the contribution of Urotensin- II and S100B in the etiology of patients diagnosed with essential hypertension, which is very commonly accompanied by anxiety and depressive symptoms.

Key Words: Essential hypertension, anxiety, urotensin-II, S100B
ÖZET

Amaç: Hipertansiyonlu bireylerde anksiyete bulgularının ortaya çıkmasında hatta hastalığın klinik bulgularının şiddetlenmesinde oksidatif stresle ve endotel fonksiyonlarıyla ilişkili olan bazı biyokimyasal parametrelerin rolü olabilir. Çalışmamızda, esansiyel hipertansiyon hastalarının anksiyete düzeyleri araştırılarak, anksiyete şiddetinin oksidatif stres parametrelerinden olan Ürotensin-II ve S100B protein seviyeleri üzerindeki etkisinin incelenmesi amaçlanmıştır. Yöntem: Çalışmaya, kan basıncı ölçümleri sonrasında venöz kan örnekleri alınan ve Sosyodemografik ve Klinik Veri Formu, Beck Anksiyete Ölçeği (BAÖ), Beck Depresyon Ölçeği (BDÖ) ölçekleri uygulanan 153 hasta dahil edildi. EnzymeLinked Immunosorbent Assay (ELISA) yöntemi ile S100B ve Ürotensin-II düzeyleri ölçüldü. Bulgular: Depresyon ve anksiyete puanları ile sistolik kan basıncı arasında pozitif yönde bir korelasyon bulunmaktaydı $(p=0.049, r=$ 0.160; $p<0.01, r=0.292$ ). Hastaların BAÖ puanları ile Ürotensin-II seviyeleri arasında pozitif bir ilişki bulunmaktaydı $(p=0.043, r=0.164)$. Ürotensin-II seviyeleri ile S100B seviyeleri arasında pozitif yönde korelasyon izlendi ( $p<0.01, r=0,711)$. Hastalardan depresyonu olan grupla, olmayan grubun serum Ürotensin-II seviyeleri arasında istatiksel olarak anlamlı fark gözlendi $(p=0.017)$. Sonuç: Çalışmamızda esansiyel hipertansiyonlu hastalarda anksiyete düzeyleri arttıkça Ürotensin-II seviyesinin arttığı tespit edilmiştir. Yine Ürotensin-II 'nin, depresyonu olan hipertansif hastalarda depresyonu olmayanlara göre daha yüksek olduğu belirlenmiştir. Çalışmamız anksiyete ve depresif semptomların çok sık eşlik ettiği esansiyel hipertansiyon tanılı hastalarda Ürotensin- II ve S100B 'nin etiyolojiye olabilecek katkısının araştırılacağı yeni çalışmalara ışık tutacaktır.

Anahtar Sözcükler: Esansiyel hipertansiyon, anksiyete, ürotensin-II, S100B 


\section{INTRODUCTION}

The risk factors for essential hypertension are shown as gender, age, education level, nutritional habits, smoking and alcohol use, sedentary life, psychosocial and cultural factors, dyslipidemia, hyperinsulinemia, hyperuricemia, and genetic predisposition (1). The most highly accused psychological factors include anxiety and depression, which may lead to autonomic symptoms particularly in this patient group (2). Individuals with essential hypertension are known to experience anxiety more intensely and for longer durations compared to normotensive individuals (3). Nevertheless, in patients with anxiety disorder, tachycardia and hypertension may be developed as a result of increased adrenaline secretion due to autonomic nervous system activation (2).

Urotensin-II (UT-II), which plays a role in the oxidative pathway and is produced as an endogenous neuropeptide, is the strongest vasoconstrictor agent determined up to this date $(4,5)$. In previous studies, UT-II was observed to have hormonal, cardiovascular and behavioral effects (6). We consider that some biochemical parameters that are associated with oxidative stress and endothelial functions may play a role in the manifestation of anxiety symptoms, and even in the intensification of clinical symptoms of the disease in individuals with hypertension. The S100B molecule also regulates cell type, energy metabolism, cellular contraction, cell-to-cell communication, intracellular signal transduction, and cellular growth (7). This study aims to examine the potential relationship between the severity of anxiety and S100B and Urotensin-II levels by investigating the grade of anxiety in patients with essential hypertension. The roles that urotensin-II and S100B molecules play in oxidative and antioxidative mechanisms, and their effects on neuroplasticity, as determined in recent studies, may underlie the pathophysiology of psychiatric disorders.

\section{METHODS}

A total of 153 subjects aged 18-65 years inclusive, who presented to the department of cardiology department and were diagnosed with essential hypertension according to the ESC Arterial Hypertension 2013 Guidelines (8) and received outpatient treatment, were included in this study. Subjects who agreed to participate in this study were informed about the inventories, blood pressure measurement, blood sampling and their clinical meaning, and verbal and written informed consent were obtained from them. Being illiterate, alcohol and substance abuse or dependency, having anxiety and related disorders and/or depression and related disorders, current or previous history of organic diseases (diabetes, asthma, infection, heart failure, Alzheimer's disease, chronic renal failure, coronary artery disease, peripheral artery disease, cerebrovascular disease, rheumatological or immunological diseases, etc.) and any medical or neurological condition that may prevent responding to inventories were set as exclusion criteria. Blood pressure measurements were taken after the administration of sociodemographic data form, the Beck Depression Inventory (BDI), and the Beck Anxiety Inventory (BAI). Blood pressure measurement was performed between 09.00 and 11.00 in the morning after the subject waited in a silent room for 15 minutes. It was checked that the subjects did not smoke, drink tea or coffee, did not intake caffeine, or did not eat within 30 minutes before their blood pressures were measured. The measurement was performed while the subject was in a sitting position without crossing their legs and speaking, and after ensuring arm support, the measurement was manually taken twice in 5-minute intervals with a sphygmomanometer on the brachial artery with the cuff surrounding at least $80 \%$ of the arm at the heart level. After applying inventories and blood pressure measurements on the patients, provided that they are on fasting conditions, a total of $5 \mathrm{cc}$ venous blood was taken from the antecubital vein into biochemistry tubes, and collected blood samples were transferred to biochemistry laboratory and centrifuged for 5 minutes at $3000 \mathrm{rpm}$. After disposing of the solid parts of blood, upper serum samples were stored at $-20^{\circ} \mathrm{C}$ until their use for the analysis of S100B and UT-II proteins. S100B and UT-II values were calculated by using the ELISA method on the serum in Biochemistry Laboratory. The cut-off value for the BDI was determined as 9, which corresponds to 'depression' for $\geq 9$ and 'non-depression' for $<9$ (9). Regarding the BAI scores, 0-7 'none', 8-15 
'mildly', 16-25 'moderately', and finally, 26-63 was determined as 'severe'. (10).

\section{Tools used in the study}

Sociodemographic and Clinical Data Form: A sociodemographic and clinical data form prepared for this study was used in all cases in line with clinical experience and information from scanned references and by considering the objectives of the study. This semi-structured form includes sociodemographic information such as age, marital status, education status, profession, gender, residence, and economic conditions, as well as clinical data such as age at disease onset, duration of disease, treatments received throughout the treatment period, habits, and history of psychiatric treatment.

Beck Anxiety Inventory (BAI): It measures the frequency of anxiety symptoms experienced by the individual. The BAI is a 21-item, 4-point Likerttype scale. The patients were asked to mark one of the following options: "None" (0), "Mildly" (1), "Moderately" (2), and "Severely" (3). The total score that can be obtained from the scale varies between $0-63$. Higher scores indicate higher levels of anxiety experienced by the person (10). The validity and reliability study for the Turkish version of the scale was conducted by Ulusoy et al. (11).

Beck Depression Inventory (BDI): It was conducted to determine the depression risk and to measure the level and severity of depressive symptoms. The BDI is a 21-item, 4-point Likert-type scale, and the total score is 63 , which is the sum of those. The total score might change between 0-63 (9). The cutoff point of the inventory was determined as 17 . The validity and reliability study of the Turkish version of the scale was conducted by Hisli (12).

\section{Biochemical Methods}

Among biochemical analysis samples, S100B protein and UT-II levels, serum human protein S100B (Biont 45 Biological Technology, Catalog no: YLA1268HU Shangai, China) and Human UII/UCN2 (SunRed Biological Technology, Catalog no: 201-12-5285) were determined by using
ELISA method in compliance with kit procedures. Measured values were recorded in nanogram/liter $(\mathrm{ng} / \mathrm{L})$ for S100B and picomoles per Liter (pmole/L) for UT-II.

Measurement of urotensin-II level with ELISA method: In order to determine serum urotensin-II levels of patients, SunRedhuman Urotensin-II ELISA kit was used, which was based on quantitative matched antibody sandwich ELISA method. The sensitivity of the UT-II kit was $0.055 \mathrm{pmol} / \mathrm{L}$ and its specificity was high (intra-assay: $\mathrm{CV}<\% 10$ inter-assay: $\mathrm{CV}<\% 12$ ).

Measurement of S100B level with ELISA Method: Bionthuman ELISA kit using the sandwich ELISA method was used for determining serum S100B levels of patients. The sensitivity of S100B was 0.22 $\mathrm{ng} / \mathrm{L}$ and its specificity was high (intra-assay: $\mathrm{CV}<\% 8$ inter-assay: $\mathrm{CV}<\% 10$ ).

\section{Statistical Analysis}

SPSS for Windows 22.0 statistics software was used for statistical analysis. Descriptive analysis was performed first in the analysis of data. Median (minimum: maximum) and $\mathrm{n}(\%)$ values were presented as descriptive statistics. Shapiro-Wilk test was used to determine whether continuous variables and inventory scores fit in normal distribution. The patients were divided into two groups as patients with or without depression. Chi-square test was used for categorical variables to examine the relationship between the groups, and T-test (MannWhitney $U$ test if normal distribution conditions were not met) was used in numerical variables for independent groups. Pearson's correlation analysis was used to examine the relationship between anxiety scores, and UT-II and S100B. $\mathrm{p}<0.05$ values were recognized as significant in the assessment of data. One Way ANOVA test (Kruskal Wallis test if normal distribution conditions were not met) was used in numerical variables for more than two groups. Simple linear regression analysis was also made in this study. 
The relationship between anxiety and serum Urotensin-II and S100B levels in patients with essential hypertension

Table 1. Sociodemographic characteristics of patients

\section{RESULTS}

A total of 153 patients with essential hypertension (106 females: $69.3 \%$ and 47 males: 30.7\%) aged 1865 were included in the study. The mean age of subjects was 52.15 \pm 9.13 (min: 18-max: 65). Considering sociodemographic characteristics, being a primary school graduate, being married and middle or low socio-economic status were the most prominent characteristics. Sociodemographic data of patients are summarized in Table 1.

Ninety of the patients $(64.8 \%)$ had no history of psychiatric treatment. Fifty-four patients $(35.2 \%)$ had a history of psychiatric treatment, and 49 of them $(32 \%)$ were still on psychiatric treatment. Twenty-eight patients (18.3\%) had generalized anxiety disorder, 14 patients $(9.1 \%)$ had depressive disorder, and 7 patients $(4.5 \%)$ had panic disorder comorbidity.

According to the European Society of Hypertension/ European Society of Cardiology 2013 classification (1), 102 patients (66.7\%) fell into stage 1 and 51 patients $(33.3 \%)$ had stage 2 hypertensive measurements. Mean systolic blood pressure was $138.1 \pm 22.6 \mathrm{mmHg}$ and mean diastolic blood pressure was $83.2 \pm 13.4 \mathrm{mmHg}$ in the with essential hypertension

\begin{tabular}{|c|c|c|}
\hline & $\begin{array}{l}\text { Patient } \\
(n=153)\end{array}$ & $\%$ \\
\hline Gender (Female) & 106 & $69 \%$ \\
\hline \multicolumn{3}{|l|}{ Educational Status } \\
\hline Middle School and below & 130 & $84.9 \%$ \\
\hline High School and above & 23 & $15 \%$ \\
\hline \multicolumn{3}{|l|}{ Marital Status } \\
\hline Married & 127 & $83 \%$ \\
\hline Single & 4 & $17 \%$ \\
\hline \multicolumn{3}{|l|}{ Socio-economic level } \\
\hline Good & 11 & $7.2 \%$ \\
\hline Middle & 74 & $48.4 \%$ \\
\hline Poor & 68 & $44.4 \%$ \\
\hline \multicolumn{3}{|l|}{ Residence } \\
\hline Province & 119 & $77.8 \%$ \\
\hline Town & 21 & $13.7 \%$ \\
\hline Village & 13 & $8.5 \%$ \\
\hline \multicolumn{3}{|l|}{ Occupation } \\
\hline Employed & 22 & $14.3 \%$ \\
\hline Unemployed & 131 & $85.7 \%$ \\
\hline
\end{tabular}

whole group. The patients were divided into three age groups as 18-35, 36-50 and 51-65 years. There was no significant difference between the variables in terms of age groups. There was a significant difference between the gender groups in terms of BAI and BDI scores $(p=0.000, p=0.001)$ (Table 2).

Mean serum UT-II level was $5.52 \pm 7.98$ pmole/L and mean serum S100B level was $29.77 \pm 27.1 \mathrm{ng} / \mathrm{L}$ in the whole group. A positive significant correlation was determined between UT-II levels and S100B levels $(\mathrm{p}<0.001, \mathrm{r}=0.71)$ (Table 3$)$.

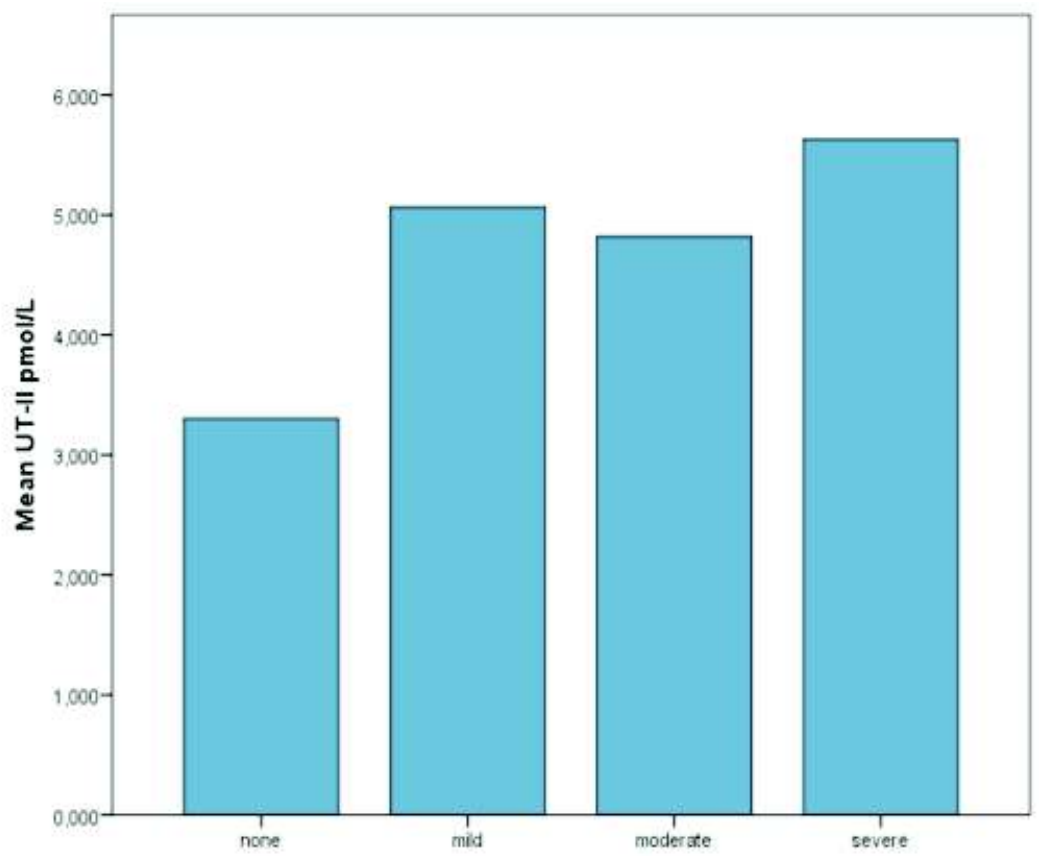

Figure 1.

Anxiety Severity 
Kazgan A, Korkmaz S, Yıldız S, Korkmaz H, Telo S, Atmaca M.

\begin{tabular}{|c|c|c|c|c|c|c|c|}
\hline & $\begin{array}{l}\text { Age } \\
18-35 \\
n=4 \\
\text { mean-std }\end{array}$ & $\begin{array}{l}36-50 \\
n=63 \\
\text { mean-std }\end{array}$ & $\begin{array}{l}51-65 \\
\mathrm{n}=86 \\
\text { mean-std }\end{array}$ & $\mathrm{p}$ & $\begin{array}{l}\text { Gender } \\
\text { Female } \\
\mathrm{n}=106 \\
\text { mean-std }\end{array}$ & $\begin{array}{l}\text { Male } \\
\mathrm{n}=47 \\
\text { mean-std }\end{array}$ & $\mathrm{p}$ \\
\hline $\begin{array}{l}\text { UT-II } \\
\text { level }\end{array}$ & $8.3-7$ & $5.5-8.3$ & $5.3-7$ & 0.74 & $5.5-7.9$ & $5.4-6.8$ & 0.93 \\
\hline $\begin{array}{l}\text { S100B } \\
\text { level }\end{array}$ & $38.9-27$ & $29.3-26$ & $29.6-28.1$ & 0.79 & $29.4-25.9$ & $30.4-29.8$ & 0.82 \\
\hline $\begin{array}{l}\text { Diastolic } \\
\text { blood } \\
\text { pressure }\end{array}$ & $68.7-13.1$ & $82.8-12.3$ & $84.1-13.9$ & 0.78 & $83.5-14.1$ & $82.5-12$ & 0.64 \\
\hline $\begin{array}{l}\text { Systolic } \\
\text { blood } \\
\text { pressure }\end{array}$ & $116.2-14.9$ & $136.1-21.7$ & $140.5-23.1$ & 0.74 & $140.1-24.5$ & $133.6-17.1$ & 0.1 \\
\hline $\begin{array}{l}\text { BAI } \\
\text { score }\end{array}$ & $14.7-6.7$ & $16.6-9.9$ & $14.8-9.4$ & 0.49 & $17.7-9.8$ & $10.7-6.9$ & $0.000 *$ \\
\hline $\begin{array}{l}\text { BDI } \\
\text { score }\end{array}$ & $5.7-7.1$ & $9.9-7.2$ & $11-7.8$ & 0.32 & $11.8-7.7$ & $7.2-6.2$ & $0.001 *$ \\
\hline
\end{tabular}

* p<0.05, p: significance level, std: standard deviation, BAI: Beck Anxiety Inventory, BDI: Beck Depression Inventory

In the inventories, the mean BDI score was $10.4 \pm 7.61$ and the mean BAI score was 15.6 \pm 9.61 . Sixty-four $(39 \%)$ patients had depression, regardless of severity. While the mean serum UT-II level was $7.24 \pm 9.95 \mathrm{pmole} / \mathrm{L}$ in the depression group, the mean serum UT-II level was $4.28 \pm 4.95$ pmole/L in the non-depression group. A statistically significant difference was found between the two groups $(p=0.017)$, but no significant difference was observed between the groups with regard to S100B levels (Table 4).

A statistically significant difference was found in UT-II levels based on anxiety levels $(p=0.007)$. We determined that this variation resulted from the difference between mild and none groups and severe and none groups. Accordingly, UT-II levels of both mild and severe groups were found to be significantly higher than the none group (Figure 1). A positive significant correlation was determined between the BAI scores and UT-II levels $(\mathrm{p}=0.043)$ $(r=0.16)$. Furthermore, there was a positive correlation between depression and anxiety scores, and systolic blood pressure $(p=0.049, r=0.160$; $\mathrm{p}<0.01, \mathrm{r}=0.292)$ (Table 3).

The results of the simple regression analysis showed that significant correlations exist between depression and anxiety levels $(B=0.691 \mathrm{p}<0.001)$, between UT-II and anxiety levels $(B=0.208$ $\mathrm{p}=0.043)$, and between UT-II and S100B $(\mathrm{B}=2.545$ $\mathrm{p}<0.001)$.

Table 3. The correlation of inventory scores and mean blood pressure with UT-II and S100B levels

\begin{tabular}{llllllll}
\hline \multirow{2}{*}{ UT-II } & & UT-II & SB100 & BAI & BDI & Mean Systole & Mean Diastole \\
\hline \multirow{2}{*}{ S B100 } & $\mathrm{r}$ & 1 & $.711^{* *}$ & $.164^{*}$ & .141 & .046 & .086 \\
\cline { 2 - 7 } & $\mathrm{p}$ & & .000 & .043 & .082 & .576 & .290 \\
\hline \multirow{2}{*}{ BAI } & $\mathrm{r}$ & $.711^{* *}$ & 1 & .101 & .021 & .032 & .079 \\
\cline { 2 - 7 } & $\mathrm{p}$ & .000 & & .215 & .800 & .690 & .329 \\
\hline \multirow{2}{*}{ BDI } & $\mathrm{r}$ & $.164^{*}$ & .101 & 1 & $.548^{* *}$ & $.292^{* *}$ & .136 \\
& $\mathrm{p}$ & .043 & .215 & & .000 & .000 & .094 \\
\hline \multirow{2}{*}{ Mean systole } & $\mathrm{r}$ & .141 & .021 & $.548^{* *}$ & 1 & $.160^{*}$ & .123 \\
& $\mathrm{p}$ & .082 & .800 & .000 & & .049 & .131 \\
\hline Mean diastole & $\mathrm{r}$ & .046 & .032 & $.292^{* *}$ & $.160^{*}$ & 1 & $.636^{* *}$ \\
& $\mathrm{p}$ & .576 & .690 & .000 & .049 & & .000 \\
\cline { 2 - 7 } & $\mathrm{r}$ & .086 & .079 & .136 & .123 & $.636^{* *}$ & 1 \\
\hline
\end{tabular}

p: significance level, r: Pearson s correlation coefficient, BAI: Beck Anxiety Inventory, BDI: Beck Depression Inventory 
The relationship between anxiety and serum Urotensin-II and S100B levels in patients with essential hypertension

Table 4. Comparison of depression and non-depression groups with regard to blood pressure, inventory scores, S100B and UT-II levels

\begin{tabular}{|c|c|c|c|}
\hline & $\begin{array}{l}\text { Depression } \\
\mathrm{n}=64 \\
\text { mean-std }\end{array}$ & $\begin{array}{l}\text { Non-depression } \\
\mathrm{n}=89 \\
\text { mean-std }\end{array}$ & $\mathrm{p}$ \\
\hline Mean systolic blood pressure & $140.40-23.51$ & $136.4-22.03$ & 0.290 \\
\hline Mean diastolic blood pressure & $83.90-13.95$ & $82.78-13.17$ & 0.612 \\
\hline Beck anxiety inventory scores & $20.87-9.98$ & $11.78-7.29$ & $0.000 *$ \\
\hline Mean serum S100B level & $31.85-29.16$ & $28.26-25.62$ & 0.420 \\
\hline Mean serum UT-II level & $7.24-9.95$ & $4.28-4.95$ & $0.017 *$ \\
\hline
\end{tabular}

\section{DISCUSSION \\ * p<0.05, p: significance level, std: standard deviation}

We determined a positive correlation between anxiety levels and Urotensin-II levels in patients with essential hypertension. UT-II levels were determined to be higher in hypertensive patients with high depression scores by the BDI compared to those who have low depression scores. A positive correlation was also determined between UT-II levels and S100B levels. In addition, a positive relationship was found between the depression and anxiety scores of patients and systolic blood pressure.

Despite some reports showing the cardioprotective effect of UT-II by activation of antioxidant enzymes, while oxidant and antioxidant are in balance (13), UT-II's direct effects on the ROT levels by activation of NADPH oxidase subunits, NOX4 and p22phox were also proven (14). Increased ROT levels and vascular smooth muscle cell proliferation may contribute the development of atherosclerosis (14). Previous studies showed that UT-II contributed to the development of hypertension by affecting the vascular and renal systems (15). In a study including 197 hypertensive patients and 197 healthy controls, it was determined that UT-II is correlated positively with systolic and diastolic blood pressure and hypertension risk increased with UT-II levels (16). In the present study, no statistically significant relationship was found between the UT-II levels of hypertensive patients and systolic and diastolic blood pressure. No healthy control group was used in this study, and blood pressure and UT- II levels were compared only in hypertensive individuals. If there existed a healthy control group, included in the study, it could have been determined whether there was a difference between the patient groups with regard to UT- II levels.
Anxiety rates were around $24-40 \%$ in patients with essential hypertension, and this affects both treatment and prognosis of chronic disorders, such as anxiety disorders, poorly (17). Sympathetic activity increases due to stress. And this stress causes an increase in systemic vascular resistance through neurohormonal mechanisms. Accordingly, the endothelial cells inside the veins with increased pressure release more vasoconstrictor substances, and eventually, hypertension is developed (18). Previous studies pointed out that a bidirectional relationship exists between anxiety and essential hypertension. In other words, patients with essential hypertension are more likely to have anxiety and vice versa (18). In addition, anxiety and depression symptoms often overlap and anxiety is often accompanied by symptoms of depression. There is also evidence for a relationship between depression and essential hypertension (19). The correlation analysis performed in our study demonstrated that a significant positive correlation exists between the BAI scores and BDI scores and systolic blood pressure of hypertensive patients. These results are consistent with the previous articles.

It was reported that UT-II promotes norepinephrine release from rat cerebrocortical areas and it was antagonized with UFP-803, a UT receptor antagonist (20). In addition, it was argued that UT-II increases epinephrine and adrenocorticotropic hormone (ACTH) levels and plays a role in hypothalamic-pituitary-adrenal response to acute stress (21). It was found that Midazolam significantly inhibits UT-II-stimulated norepinephrine release from rat cerebrocortical areas and it was stated that this mechanism might be mediated via GABA-A (22). There are rat studies in which UTII was administered to rats as intracerebrovascular injection, which was proven to increase the number of rapid eye movement sleep stage and appetite, and increased tendency to depression and anxiogenic motor movements (7). All above-mentioned 
findings strengthen the role of UT-II on the etiology of anxiety. One of the rationales of this study was to examine the relationship between the anxiety and depression inventory scores and UT-II levels in patients with essential HT. We found a significant correlation between UT-II levels and anxiety levels. Although the correlation analysis showed that this correlation was not significant and the power of the relationship was weak, it can be suggested that the further analysis conducted has strengthened the existence of this correlation. Among study results, UT-II levels were higher in patients with high depression scores compared to those with low scores and this difference was found to be statistically significant.

There are results supporting oxidative stress mechanism in schizophrenia, bipolar disorder, depression, substance abuse disorder, autism, adult attention deficit and hyperactivity disorder, panic disorder, obsessive-compulsive disorder and social phobia in psychiatric studies. As these studies have shown that patients diagnosed with panic disorder and obsessive-compulsive disorder may have higher levels of antioxidant enzymes in their erythrocytes $(23,24)$, increased lipid peroxidation in generalized anxiety disorder and suppressed antioxidant activity in panic disorder were also demonstrated $(25,26)$. However, there is only a small number of mouse studies investigating the relationship between oxidative stress and anxiety (27). In these mouse studies, it has been mentioned that the glutathione reductase 1 gene is protective against oxidative stress and anxiety. While excessive local expression of these genes in rat brain results in increased anxiety-like behavior, local inhibition of these genes reduced anxiety-like behavior (28). In the mouse models, vitamin $\mathrm{E}$ depletion was found to be associated with increased oxidative stress markers and anxiety behaviors and a positive correlation was observed between peripheral blood oxidative stress markers and anxiety behaviors (29). Anxiolytic GABA-A receptor activity is regulated by redox stress mechanisms (30). Since the intracerebroventricular administration of UT-II resulted in increased ROT levels in rat experiments (31) and the mechanisms of S100B as a protein causes an increase in ROT levels were examined (32), it is not surprising that these markers may also have an effect on anxiety levels. There are studies that showed S100B proteins may play a role in the pathogenesis of depression (33). S100B acts partially on serotonin receptors and serotonin also changes central S100B concentrations. It has been suggested that $\mathrm{S} 100 \mathrm{~B}$ is associated with mood disorders, including depressive disorder, due to both its interactions with the serotonin receptor (33) and also its effect on oxidant and antioxidant pathways (34). S100B causes increased cellular oxidative stress and response to inflammatory cytokines at micromolar concentrations by interacting with RAGE. S100B's RAGE-mediated ROT production is of interest in mood disorders (35). In addition, this mechanism induces endothelial dysfunction and establishes a ground for vascular diseases such as atherosclerosis and hypertension (36).

Located in astrocyte and oligodendrocytes, S100B was determined at nanomolar concentrations rather than micromolar concentrations in mood disorders, and for this reason, high S100B levels have the potential of being an indicator of a degenerative or regenerative process in a disrupted blood-brain barrier, according to glial cell pathology (36). There is no study that directly examines protein S100B and anxiety levels. In this study, S100B levels were higher in patients with anxiety compared to those without anxiety, but this difference was not statistically significant. Results of this study were considered to mean that S100B may possibly be significantly higher in studies to be conducted with a larger samples.

There is no study about the effects of antidepressant treatment on serum UT-II levels in the literature. Different results have been reported in clinical studies examining the effect of antidepressant treatment on the S100B levels. There are studies reporting that serum S100B levels of patients increased significantly after antidepressant treatment (37), on the other hand, it decreased significantly (38). However, six studies reported that there is no significant effect of antidepressant treatment on serum or plasma S100B levels (39-44). Since most studies did not report any effect on S100B levels, we did not exclude the use of antidepressants in our study.

There was a positive relation between UT-II levels 
The relationship between anxiety and serum Urotensin-II and S100B levels in patients with essential hypertension

and S100B levels in this study. Serum UT-II levels of patients may be an independent reason for hypertension and anxiety development, apart from other possible variables. We speculate that if S100B levels could be measured at the time interval with the highest anxiety levels in hypertension patients, more significant results might be obtained in patients with higher Beck inventory scores. There is a small number of animal studies investigating the relation between oxidative stress and anxiety (27). The present study aims to investigate the relationship between anxiety, hypertension and biological stress. Our study has several limitations such as being a cross-sectional study, findings being based on self-reported data, the absence of any psychiatric interview, and evaluation of anxiety and depression by only self-reports. Only patients who presented to the department of cardiology were included in the study. The genetic variations of S100B and UT-II receptors, body mass index and multiple drug and combination therapy use were not included in this study.

\section{CONCLUSION}

Consequently, it is suggested that UT-II levels were determined to be higher in hypertensive patients with high depression scores as defined by BDI com- pared to those who have low depression scores. Furthermore, a positive correlation was determined between UT-II levels and S100B levels of patients, which is suppotive of the importance of oxidative stress in the pathophysiology of anxiety and depression. However, further studies with larger samples are needed to verify these results.

\section{Statement of Ethics}

All procedures performed in this study were in accordance with the ethical standards of the institutional and/or national research committee and with the 1964 Helsinki declaration and its later amendments or comparable ethical standards. No animal or human studies were carried out by the authors for this study. The patients had given their written informed consent. Ethics committee approval was taken with the decision of Firat University Faculty of Medicine Noninterventional Studies Ethics Committee dated 14/12/2017 nr. 230162.

\section{REFERENCES}

1. Ewald DR, Haldeman LA. Risk Factors in Adolescent Hypertension. Glob Pediatr Health 2016; 3: 2333794X15625159.

2. Özen EM, Serhadlı ZN, Türkcan AS, Ülker GE. Somatization in Depression and Anxiety Disorders. The Journal of Psychiatry and Neurological Sciences 2010; 23:60-65.

3. Liu MY, Li N, Li WA, Khan H. Association between psychosocial stress and hypertension: a systematic review and metaanalysis. Neurol. Res 2017; 39: 573-580. doi: 10.1080/01616412.2017.1317904

4. McDonald J, Batuwangala M, Lambert DG. Role of urotensin II and its receptor in health and disease. J Anesth 2007; 21: 378-389.

5. Tabur S, Korkmaz H, Eren MA, Oğuz E, Sabuncu T, Aksoy N. Urotensin-II level and its association with oxidative stress in early diabetic nephropathy. J Diabetes Complications 2015; 29(1):115-119.

6. Jégou S, Cartier D, Dubessy C, Gonzalez BJ, Chatenet D, Tostivint H, Scalbert E, LePrince J, Vaudry H, Lihrmann I. Localization of the urotensin II receptor in the rat central nervous system. J Comp Neurol 2006; 495:21-36.

7. Adami C, Sorci G, Blasi E, Agneletti AL, Bistoni F, Donato R. S100B expression in and effects on microglia. Glia 2001; 33:131-142.

8. 2016 ESC Guidelines for the diagnosis and treatment of acute and chronic heart failure: The Task Force for the diagnosis and treatment of acute and chronic heart failure of the European

Turkish J Clinical Psychiatry 2021;24:315-323
Correspondence address: M.D. Aslı Kazgan, Siverek State Hospital, Department of Psychiatry, Şanlıurfa, Turkey dr.kazgan@hotmail.com

Society of Cardiology (ESC) Developed with the special contribution of the Heart Failure Association (HFA) of the ESC. Eur Heart J 2016; 37:2129-2200.

9. Beck AT, Steer RA, Brown GK, Gregory KB. "Manual for the beck depression inventory-II. San Antonio, TX: Psychological Corporation 1996; 82.

10. Beck AT, Epstein N, Brown G, Ster RA. An inventory for measuring clinical anxiety: psychometric properties. J Consul Clin Psychol 1988; 56:893-897.

11. Ulusoy M, Sahin NH, Erkmen H. Turkish version of the Beck anxiety inventory: psychometric Properties. J Cogn Psychother Int Q 1998; 12: 163-172.

12. Hisli N. Beck depresyon envanterinin üniversite öğrencileri için geçerliği, güvenirliği. Psikoloji Dergisi 1989; 7-13.

13. Peng H, Zhang M, Cai X, Olofindayo J, Tan A, Zhang Y. Association between human urotensin II and essential hypertension-a 1:1 matched case-control study. PloS One 2013; 8(12): 81764. https://doi: 10.1371/journal.pone.0081764.

14. Djordjevic T, BelAiba RS, Bonello S, Pfeilschifter J, Hess J, Gorlach, Human urotensin II is a novel activator of NADPH oxidase in human pulmonary artery smooth muscle cells. Arteriosclerosis, thrombosis, and vascular biology 2005; 25(3): 519- 525.

15. Watson AM, May CN. Urotensin II, a novel peptide in central and peripheral cardiovascular control. Peptides 2004; 25:1759-1766. 
16. Sugo T, Murakami Y, Shimomura Y, Harada M, Abe M, Ishibashi Y, Kitada C, Miyajima N, Suzuki N, Mori M, Fujino M. Identification of urotensin II-related peptide as the urotensin II immunoreactive molecule in the rat brain. Biochem Biophys Res Commun 2003; 310:860-868.

17. Gao S, Oh YB, Park BM, Park WH, Kim SH. Urotensin II protects ischemic reperfusion injury of hearts through ROS and antioxidant pathway. Peptides 2012; 36(2):199-205. doi: 10.1016/j.peptides.2012.05.004. Epub 2012 May 15.

18. Liu MY, Li N, Li WA, Khan H. Association between psychosocial stress and hypertension: a systematic review and metaanalysis. Neurol Res 2017; 39: 573-580. doi: 10.1080/01616412.2017.1317904.

19. Ginty AT, Carroll D, Roseboom TJ, Phillips AC, De Rooij SR. Depression and anxiety are associated with a diagnosis of hypertension 5 years later in a cohort of late middle-aged men and women. J Hum Hypertens 2013; 27: 187-190. doi: 10.1038/jhh.2012.18

20. Matsumoto Y, Abe M, Watanabe T, Adachi Y, Yano T, Takahashi H, Sugo T, Mori M, Kitada C, Kurokawa T, Fujino M. Intracerebroventricular administration of urotensin II promotes anxiogenic-like behaviors in rodents. Neurosci Lett 2004; 358: 99-102.

21. Watson AM, May CN. Urotensin II, a novel peptide in central and peripheral cardiovascular control. Peptides 2004; 25 : $1759-1766$

22. Kawaguchi Y, Ono T, Kudo M, Kushikata T, Hashiba E, Yoshida H, Kudo T, Furukawa K, Douglas SA, Hirota K. The Effects of Benzodiazepines on Urotensin II Stimulated Norepinephrine Release from Rat Cerebrocortical Slices. Anesth Analg 2009; 108(4): 1177-1181. doi: 10.1213/ane.0b013e3181981faa

23. Ng F, Berk M, Dean O, Bush AI. Oxidative stress in psychiatric disorders: evidence base and therapeutic implications. Int J Neuropsychopharmacol 2008; 21: 1-26.

24. Hunt BD, Leong LN, Lambert DG. A rat brain atlas of urotensin-II receptor expression and a review of central urotensin-II effects. Naunyn-Schmied Arch Pharmacol 2010; 382: $1-31$

25. Bulut M, Selek S, Bez Y, Karababa FI, Kaya MC, Gunes M, Emhan A, Aksoy N, Sir A. Reduced PON1 enzymatic activity and increased lipid hydroperoxide levels that point out oxidative stress in generalized anxiety disorder. J Affect Disord 2013; 150: 829-833.

26. Ozdemir O, Selvi Y, Ozkol H, Tuluce Y, Besiroglu L, Aydin A. Comparison of superoxide dismutase, glutathione peroxidase and adenosine deaminase activities between respiratory and nocturnal subtypes of patients with panic disorder. Neuropsychobiology 2012; 66: 244-51.

27. Ersan S, Bakir S, Ersan EE, Dogan O. Examination of free radical metabolism and antioxidant defence system elements in patients with obsessive-compulsive disorder. Prog Neuropsychopharmacol Biol Psychiatry 2006; 30: 1039-1042.

28. Hovatta I, Tennant RS, Helton R, Marr RA, Singer O, Redwine JM, Ellison JA, Schadt EE, Verma IM, Lockhart DJ, Barlow C. Glyoxalase 1 and glutathione reductase 1 regulate anxiety in mice. Nature 2005; 38: 662-666.

29. Bouayed J, Rammal H, Younos C, Soulimani R. Positive correlation between peripheral blood granulocyte oxidative status and level of anxiety in mice. Eur J Pharmacol 2007; 564: 146149.

30. Calvo DJ, González AN. Dynamic regulation of the GABAA receptor function by redox mechanisms. Mol Pharmacol 2016; 90: $326-333$

31. Bülbül F, Alpak G, Ünal A, Cöpoğlu S, Orkmez M, Virit O, Savas HA. New molecule in the etiology of schizophrenia: Urotensin II. Psych Clin Neuro Sci 2014; 68 (2): 133-136.

32. da Rosa MI, Simon C, Grande AJ, Barichello T, Oses JP, Quevedo J. Serum S100B in manic bipolar disorder patients: systematic review and meta-analysis. J Affect Disord 2016; 206 : 210-215.

33. Schroeter ML, Steiner J, Schonknecht P. Further evidence for a role of S100B in mood disorders: a human gene expression mega-analysis. J Psychiatr Res 2014; 53: 84-86.

34. Villarreal A, Seoane R, Torres AG, Rosciszewski G, Angelo MF, Rossi A, Barker PA, Ramos AJ. S100B protein activates a RAGE-dependent autocrine loop in astrocytes: Implications for Its role in the propagation of reactive gliosis. J Neurochem 2014; 131: $190-205$

35. Kroksmark H, Vinberg M. Does S100B have a potential role in affective disorders? A literature review. Nordic Journal of Psychiatry 2018; 72:462-470.

36. Ritthaler U, Deng Y, Zhang Y, Greten J, Abel M, Sido B. Expression of receptors for advanced glycation end products in peripheral occlusive vascular disease. Am J Pathol 1995; 146: 688.

37. Jang BS, Kim H, Lim SW, Jang KW, Kim DK. Serum S100B levels and majör depressive disorder: its characteristics and role in antidepressant response. Psychiatry Investig; 2008; 5:193-198.

38. Schroeter ML, Abdul-Khaliq H, Diefenbacher A, Blasig IE. S100B is increased in mood disorders and may be reduced by antidepressive treatment. Neuroreport 2002; 13: 1675-1678.

39. Arolt V, Peters M, Erfurth A, Wiesmann M, Missler U, Rudolf S, Rothermundt M. S100B and response to treatment in major depression: a pilot study. Eur Neuropsychopharmacol 2003; 13: 235-239.

40. Hetzel G, Moeller O, Evers S, Erfurth A, Ponath G, Arolt V, Rothermundt M. The astroglial protein S100B and visually evoked event-related potentials before and after antidepressant treatment. Psychopharmacology 2005; 178(2-3): 161-166.

41. Schroeter ML, Abdul-Khaliq H, Krebs M, Diefenbacher A, Blasig IE. Serum markers support disease-specific glial pathology in major depression. J Affect Disord 2008; 111: 271-280.

42. Tsai MC, Huang TL. Increased activities of both superoxide dismutase and catalase were indicators of acute depressive episodes in patients with major depressive disorder. Psychiatry Res 2016; 235: 38-42.

43. Fang Y, Xiao SF, Zhang SY, Qiu Q, Wang T, Li X. Increased plasma S100b level in patients with major depressive disorder. CNS Neurosci Ther 2016; 22: 248-250.

44. Rothermundt M, Arolt V, Wiesmann M, Missler U, Peters M, Rudolf S, Kirchner H. S-100B is increased in melancholic but not in non-melancholic major depression. J Affect Disord 2001; 66: 89-93. 